\title{
Creating an ownership society? Social security reform and the temporalities of libertarian rhetoric
}

\section{Simone Knewitz}

University of Bonn, Germany

\begin{abstract}
Former US president George W. Bush's idea of the United States as an 'ownership society' can be considered as the rhetorical apex of a conservative, libertarian push for a more marketdriven restructuring of American social institutions. Reformers in the Bush administration particularly targeted Social Security, a popular American institution and signature achievement of the New Deal era, aiming to replace a system of solidarity with one of individual responsibility and partial privatization. Returning to the time of the early 2000s, this article analyzes the rhetoric of the ownership society as a libertarian utopian social vision - a future, more perfect community the United States should aspire to grow into. It argues that the political discourse on Social Security propagated by the Bush administration relied on rhetorical strategies characterized by an engagement of temporalities. On the one hand, ownership discourse invoked the nation's past achievements and traditional values secured during the American Revolution and guaranteed in the nation's founding documents. On the other hand, the administration framed the alleged urgency of the reforms by making projections about the future and using these to raise questions about the present system of Social Security provision. In this way, earlier debates over Social Security reform provide a valuable perspective on the contemporary nexus of finance and temporality.
\end{abstract}

\section{Keywords}

Social security, Bush administration, libertarianism, ownership society, political rhetoric

\section{Introduction}

In early 2002, during the second year of his administration, then-President George W. Bush began to promote the idea of the United States (US) as an 'ownership society'. "Every American deserves to be an owner in the American Dream", he claimed. "That dream includes a sound pension plan and adequate private savings, and it is ultimately completed by Social Security reform" (Bush, 2005a: 310). Bush continued to advocate an American society

\section{Corresponding author:}

Simone Knewitz, Department of English, American, and Celtic Studies, University of Bonn, Regina-Pacis-Weg 5, 53113 Bonn, Germany. Email: sknewitz@nap-uni-bonn.de 
structured around private property in his speeches on more than 170 occasions, featuring the concept prominently in his 2004 reelection campaign and continuing to do so until the end of his presidency in 2009. This rhetoric of the ownership society interwove concrete policy proposals with depictions of property ownership as a moral, cultural, and quintessentially American value. Bush envisioned a society that made ownership accessible to all its members, thereby bestowing upon them "independence" and "dignity" (Bush, 2006c: 929). Property ownership, he claimed, was an intrinsically ethical value: citizens would be enabled to control their own destiny by pursuing economic opportunities and making their own choices, thereby also participating in the democratic decision-making processes of the country. Emphasizing an orientation towards the future and celebrating optimism, this social vision appeared as a utopian blueprint for a better community.

Bush's ownership society can be considered as the rhetorical apex of the conservative push for a more market-driven restructuring of American social institutions as it has evolved in the US since the late 1970s. Part of an increasingly powerful libertarian movement which had gained momentum since the Reagan era, it envisioned reform projects - such as the expansion of homeownership and the privatization of the health care system - that sought to 'empower' citizens by shifting responsibility and risk from the government to the individual. In this context, libertarians particularly targeted Social Security, a popular American institution and signature achievement of the New Deal era. In a political climate that increasingly disfavored 'big government', they saw the chance to replace a system of solidarity with one of individual responsibility and partial privatization. Thus, the debate on Social Security reform exemplifies a concerted effort to redraw the boundaries between the public and the private, the state and the individual. The ownership society did not constitute a proposed solution to a preexisting social problem; rather, as I will demonstrate, the Bush administration strategically employed the concept so as to frame social reality in such a way as to create the issues that needed fixing. The remedy that the libertarian movement proposed was a minimal state with a maximum of individual economic liberties. ${ }^{1}$

Social Security as the object of the Bush administration's reform projects provides a particularly apt example for studying the nexus of finance and temporality. Built on the principle of solidarity, the US system of social security relies on a long-term strategy, in which today's taxpayers finance current retirees and, in return, become tomorrow's beneficiaries. In this sense, Social Security is inherently future-oriented. Significantly, the system's temporal mechanisms depend on the relative stability of economic structures, with shifts in demographics or wage allocation potentially threatening its sustainability. However, since the future remains fundamentally uncertain, social security policies have to rely on projections modeled on the present and assumptions about the future, both of which may be contested. Political decisions in the realm of social security are thus intrinsically linked to ideological frameworks, as they touch upon issues of wealth distribution and are far-reaching in their longterm consequences. The political discourse on Social Security propagated by the Bush administration in particular relied on rhetorical strategies characterized by an engagement of temporalities. On the one hand, ownership discourse invoked the nation's past achievements secured during the American Revolution and guaranteed in the nation's founding documents, particularly those associated with traditional values such as individualism, freedom, and property rights. On the other hand, the administration framed the alleged urgency of the reforms by making projections about the future, and by suggesting that the prevailing system of social security provision was on the verge of collapse.

More generally, the Bush administration's reform proposals were tied to processes of privatization and financialization, which affected the temporal structures of social institutions 
and the position of individuals within them, particularly in terms of how they dealt with future risks. In the case of Social Security, the administration proposed that wage earners could divert parts of their tax contributions from the system into private investment accounts, thus turning insurance into a form of financial investment. This meant a shift from a collective system of insurance - an approach which aimed not at maximizing profits, but at minimizing future risks - toward a system of individual investment decisions in which higher returns could be generated by taking on higher future risks. In an investment model, individuals do not insure themselves against their own life risks, but instead seek to capitalize on the risks of the financial markets - a model which thus not only shifts but also increases future risks for the individual, requiring risk-averse citizens to become risk takers. ${ }^{2}$ The concept of the ownership society aimed to facilitate this transformation by positing the taking-on of financial risks as self-ownership, independence, control, and responsibility for the individual citizen.

As Robert Asen has noted, policies mediate "rhetorical and material forces" in a society, while "the process of policymaking foregrounds the role of rhetoric as a constitutive force" (Asen, 2009: 7, 9). Rhetoric thus assumes an important role in the making of meaning via the framing of social phenomena and social problems. Political actors wishing to alter existing institutions, such as the Social Security system in the US, need to present coherent and attractive alternative visions before they can go about constructing the reform of established policies as a necessity (Béland, 2007: 93). Bush and his allies, most prominently libertarian think tanks such as the Cato Institute, projected a comprehensive ideal of an American society structured around ownership that drastically reinterpreted the relationship of the individual to the government. Their arguments were grounded in a philosophical tradition, represented by figures like Friedrich von Hayek, Milton Friedman, and Robert Nozick, that rejects Social Security as an unethical program of wealth redistribution. Though this particular reform project ultimately did not come to fruition, the libertarian rhetoric yielded considerable influence on the public discourse, shaping the popular perception of government programs and entitlements.

In this article, I analyze the rhetoric of the ownership society as a utopian social vision - a future, more perfect community the US should aspire to grow into. My characterization of the libertarian project as a form of utopianism should not be understood as a negative judgment on the possibility of its realization. Rather, my use of the term 'utopia' is inspired by Nozick's own attempt to imagine the best possible community that may be morally justified according to libertarian values. For Nozick (1974), such a community can only be a minimal state that allows a maximum of agency for individuals. Between different models of political organization, he suggests, the minimal state alone makes it possible to realize every person's and every group's specific vision of the good society (Nozick, 1974: 297-334). In characterizing the minimal state as a utopia, Nozick frames it as an inspiring, positive vision of political life rather than one merely defined by absences. As I will demonstrate, the Bush administration and its libertarian allies similarly attempted to craft an attractive political ideal.

\section{Social Security as a blueprint for libertarian utopia}

Bush's vision of the ownership society posits a primacy of the rights and responsibilities of the individual citizen over society, which, in his speeches, is translated into the recurring theme of the citizen as stakeholder: "If you own something in America, you own a stake in America's future" (Bush, 2005a: 311). He likens the citizen to a stock investor: property privately owned here figuratively appears as shares of 'Corporation America', promising the owner a profit for 
his or her investment through dividend payments and increased future stock prices. The owner-citizen "buys into the future of America" (Bush, 2007b: 1782) and thereby participates in the process of wealth creation and the fate of the nation. Like a stockowner, the citizen is invested in the future political development of the country, and particularly in the policies that regulate property. According to Bush, ownership is "an important part of making sure people have a interest [sic] in the future of our country. If you own something, you want to make sure Government makes the right decision so you can continue to own it" (Bush, 2007a: 1235). The citizen as stakeholder, then, is more than a metaphor. Bush presents stakeholding quite literally as protecting one's material interests, and thereby redefines stakeholding as a form of shareholding. He thus advances a form of democracy based on the model of the corporation as a passive mode of control, not an active form of participation. Depicting the state and the citizen in oppositional roles, the property relation emerges as a defining characteristic of the democratic state.

In positing property ownership as the prerequisite to political participation, Bush's rhetoric harks back to a time in US history when voting rights were tied to owning property. By distinguishing between owners and non-owners, this vision of democracy implicitly questions the political status of those not owning any property. Yet he also emphasizes that he does not envision an exclusive society of the few by promising to expand ownership to include all citizens: "we want 100 percent of our people to be a part of the ownership society" (Bush, 2006: 159). Bush offers inclusiveness as a distinctly American feature as he asserts: "I'm talking about ownership for all people, not just a certain type of person. We want ownership to be a part of every neighborhood. And it's happening in America. It's really what makes us such a wonderful country, isn't it, when people from all walks of life can say, "I own something'" (Bush, 2007a: 1225). Citing homeownership rates at all-time highs as evidence, Bush depicts the US as being in the process of realizing its potential as a community of owners, in which racial and economic differences - the distinction between "certain type[s] of person[s]" with access to property and those without - would ultimately disappear.

For the individual, the ownership society not only holds the promise of financial security "a nest egg you can call your own and Government can never take away" - but, more generally, seeks to provide "a path to greater opportunity, more freedom, and more control over your own life" (Bush, 2007c: 1857). Owners do not depend on the government, neither materially nor for directions of how to lead their lives; and they "take responsibility for the decisions they make" (Bush, 2006c: 929). Bush therefore frames the absence of government intervention as an increase in individual agency and autonomy. He introduces 'responsibility' as a key term that suggests individual empowerment, but also imbues it with an ethical dimension. Responsibility not only means to act self-interestedly and autonomously, but also to respect other people and take care of one's community. Ownership, for Bush, entails obligations, including an obligation to act compassionately. Responsibility in this way "served as the cupola connecting compassion and ownership, thereby revealing the spiritual dimension of ownership" (Asen, 2010: 117-18).

The Cato Institute, a libertarian think tank in Washington, DC, sought to deliver a philosophical foundation for the ownership society and positioned itself as one of the concept's staunchest supporters. Tom G. Palmer, a political scientist at George Mason University in Fairfax, Virginia, and David Boaz, Executive Vice President at the Cato Institute, each published articles in 2004 describing the ownership society as "a society of responsibility, liberty and prosperity" (Palmer, 2004: para. 1), reinforcing the themes and key signifiers of Bush's speeches. Framed as philosophical deliberation, their discussions proceed without reference to concrete social or political problems, instead focusing on the moral and 
ethical dimension of ownership. The three abstract principles Palmer invokes - responsibility, liberty, and prosperity - already suggest a superior form of social organization on the economic, political, and personal level. Private property ownership, they argue, enables the most efficient use of resources, promises a diffusion of power in society as well as individual agency, and creates an environment for human flourishing. They thus frame in popular terms arguments advanced by liberal and libertarian philosophers and economists in favor of a private property system. ${ }^{3}$

Belief in the efficiency of markets constitutes the main pillar of the libertarian vision. Markets allow for a prosperous society, Palmer holds, because they generate wealth for individuals and are able to coordinate activity without the intervention of a centralized authority. Palmer here relies on the famous metaphor of the 'invisible hand' derived from Adam Smith - the idea that spontaneous self-interested behavior generates the most socially beneficial outcome. Significantly, he transposes the notion of market efficiency from the economic to the political sphere, arguing that the market model provides a paradigm for cooperation without conflict, without the "squabbling [...] characteristic of political control" (Palmer, 2004: para. 10). Guided by the principle of efficiency, then, political negotiations over resources become dispensable, as people will take care of their needs via private transactions and choices. A society led by an invisible hand presumes the existence of one efficient and just way of distributing resources, making political discourse superfluous.

By relying on individual choice and decision-making, Palmer argues, the market model also "induces people to act responsibly" (2004: para. 2). In a society structured around private ownership of resources, it is in the individual's best interest to take care of one's property there is no "tragedy of the commons" (Hardin, 1968: 1243), no squandering or exploitation of shared resources for private gain. In this vein, Boaz even proposes that an ownership society would help improve the environment. He gives the example of a timber company, which, acting in its own self-interest, would not cut down all trees on its land at once, and plant new trees to replace the ones they felled. "They may not be moved by a concern for the environment", he writes, "but the future income from the property is also a powerful incentive" (Boaz, 2004: para. 11). From this specific example he generalizes that only in a private property system do citizens have an incentive to worry about pollution and environmental destruction, since they seek to protect "the future value of property" (Boaz, 2004: para. 11). Evidently, this generalization is problematic, as Boaz's example does not account for externalities. Different examples, such as that of a chemical plant polluting natural water bodies with sewage, would imply the opposite - namely, that destruction increases if the company lacks economic incentives in the absence of government regulation. ${ }^{4}$ Boaz here strategically tackles an area in which markets are often considered to be harmful in order to emphasize what he see as the fundamentally ethical nature of private property ownership.

Both Boaz and Palmer advance their libertarian vision of a private property system by contrasting it unfavorably with the alternative of state socialism. In a system in which "government owns all property", Boaz writes, "individuals have little protection from the whims of politicians" (2004: para. 12). Phrased in such an antagonistic way, capitalism appears as the superior form of social organization, because "it diffuses power" (Boaz, 2004: para. 12). In Boaz's and Palmer's conception, the ownership society appears, almost paradoxically, as the ultimate realization of a classless society in which all members have equal access to political power and resources. Both authors thereby develop the ownership society as a capitalist utopia which promises to put into practice the tenets once formulated by the proponents of socialism. By operating on the assumption of a fundamental contrast between socialism and capitalism, however, they circumvent the much more pertinent question of how the ownership 
society compares to the actually existing capitalist system in the contemporary US. They also evade a discussion of any positive function for governments, which appear only as entities whose power needs to be clipped. Strictly realized, the ownership society would be a community in which all state functions have been replaced by market mechanisms. In this philosophy, "market modalities constitute an ethically superior realm of society because they enable more authentic expressions of human activity" (Asen, 2010: 110).

Boaz and Palmer, then, like Bush, depict the ownership society as an attractive vision that promises individual autonomy, agency, and ultimate self-realization. Owners "feel more dignity, more pride, and more confidence"; they "are empowered by freeing them from dependence on government handouts and making them owners instead, in control of their own lives and destinies" (Boaz, 2004: para. 2). The aim of the ownership society, it becomes apparent, is to create the owner as a specific type of subject. Owners not only strive to improve their property, but also their selves, by cultivating "healthy habits of behavior", as Geoff Mulgan, a top aide to former British prime minister Tony Blair once suggested (quoted in Boaz, 2004: para. 3). Life in the ownership society entails the disciplining of the self and demands specific forms of behavior. Specifically, the ownership society asks the individual to take on responsibilities for risks formerly borne by public institutions, as became quickly apparent in the reform proposals advanced by the Bush administration.

\section{A nation of homeowners?}

Between 2002 and 2004, the Bush administration identified specific policy areas to realize the ownership society. Reform proposals included the expansion of homeownership; the privatization of Social Security, health care, and public schools; as well as plans to tighten bankruptcy laws, replace income and wealth taxes with consumption taxes, and eliminate welfare "entitlements" (Wray, 2005b: 7). Bush's focus on homeownership, especially during the early years of his presidency, held large symbolic significance. With Americans traditionally associating property ownership with the home, Bush could introduce his far-reaching transformations of public institutions by promoting the ownership society in an area already considered to be a unanimous good and a mainstay of federal policy and presidential rhetoric. Moreover, by particularly addressing minority citizens, Bush was able to emphasize inclusiveness. He started this campaign in 2003 with the American Dream Downpayment Initiative (ADDI), which supported prospective low-income homeowners that were unable to contribute a down payment for a mortgage. The initiative provided $\$ 200$ million annually for down payment assistance, offering grants of up to $\$ 10,000$ dollars or $6 \%$ of the purchase price of the home (whichever was greater) as a grant for low-income first-time homebuyers. ADDI was signed into law in December 2003 and mainly targeted minority families, traditionally underrepresented among homeowners. ${ }^{5}$ During a time in which the private financial industry was already expanding its credit products to sell loans and mortgages to previously excluded groups with low incomes and no assets, Bush declared his goal of helping 5.5 million minority families to own their first own home within ten years. As Cuevas (2012: 614) notes, Bush's acknowledgement of the gap between Anglo-American and minority homeownership rates "was a significant discursive shift for a president who had shown little concern for black or brown people". She argues that the actual motivation behind his support for minority ownership was to cater to the industry that sold the financial products involved; African Americans and Hispanics were thus "allowed to enter the market not as active agents [...] but as consumers of debt-as-commodity” (Cuevas, 2012: 615). 
Tying in with a century-long history of federal homeownership initiatives, ADDI was not merely the least controversial of Bush's efforts to increase private ownership, but in fact gathered broad bipartisan support (Mian et al., 2008). More specifically, the act bore stark resemblance to a similar effort by Bush's predecessor Bill Clinton, who had already sought to increase homeownership with his National Homeownership Strategy in $1995 .{ }^{6}$ Clinton had taken office when the homeownership rate hovered around 64\%, having dropped from its alltime high of $65.8 \%$ in 1980 . He aimed to expand homeownership to $67.5 \%$ by the year 2000 (the rate actually climbed to $67.7 \%$ in the third quarter of 2000). Clinton did not institute new federal programs to help more families become homeowners, but instead relied on what he called "an alliance of the public and the private sector" (Clinton, 1995: 808). In concrete terms, this meant further deregulation of the financial industry, which the Carter and Reagan administrations had already set into motion. Under Clinton, subprime mortgage loans and 'predatory lending' - exploitative, high-cost loans - gathered momentum. ${ }^{7}$ In 1995, the overall volume of the subprime mortgage loan market was $\$ 90$ billion; the amount then doubled over the next three years, while the number of subprime lenders also increased significantly (Canova, 2008: 43). When George W. Bush was elected president, the mechanisms which would cause the 2007-08 financial crisis were already in place; the housing bubble was already building and would reach its climax in 2004 - the very moment of Bush's second presidential campaign and his campaign to expand homeownership. ${ }^{8}$

While supporting policies that advanced the financialization of the housing market, Clinton (1995: 808) rhetorically advocated homeownership as something families "were entitled to [...] as part of the American dream". He depicted his effort as a direct continuation of the housing programs introduced by Franklin D. Roosevelt and Harry Truman - the Federal Housing Administration and the Gl bill of rights. In the 1980s, Clinton argued, as the homeownership rate decreased, "that dream began to slip away". In response, he set out "to restore that dream, to grow the middle class, shrink the under class, promote the mainstream values of work and responsibility, family and community, and reform Government in a way that would enhance opportunity and shrink bureaucracy" (Clinton, 1995: 807). For Clinton, homeownership was "about the way we live as a people and [the] kind of a society we're going to have"; it enabled people to "have a stake in a better life", it "strengthen[ed] our economy [...] and buil[t] better citizens" (1995: 806, 807, 808). In this way, Clinton advocated many of the values that would become characteristic of Bush's rhetoric as well.

In contrast to Clinton, however, Bush advocated a far more expansive vision of ownership. Clinton rhetorically remained focused on homeownership and avoided the term 'property', whereas Bush usually listed homeownership as only the first of several goals of the ownership society. He thus conflates the ownership of houses with that of other financial assets, thereby transposing the positive connotations of the home as a place of privacy and security and as an investment in one's future (wealth) to these other forms of private ownership. The promotion of homeownership as his first ownership-related policy proposal, then, strategically served to portray his administration's broader efforts towards privatization and financialization in a positive light, ${ }^{9}$ a move that was bolstered by the steady increase in homeownership and property values at the time. As Béland (2007) has noted, ADDI was actually rather modest in its scope; its objective was to help approximately 40,000 families per year with their down payment, as well as provide insurance through the Federal Housing Administration for firsttime homebuyers who did not contribute a down payment. ADDI therefore concerned only a fraction of the whole housing market. ${ }^{10}$ The limited reach of the policy thus "contrasts strongly with the president's optimistic and ambitious rhetoric" (Béland, 2007: 98). ${ }^{11}$ 
The fact that Bush's ADDI policy was of a primarily rhetorical character underlines the symbolic significance of homeownership for the political vision of the ownership society. The home, with its connotations of privacy and security, as well as its practical function for many Americans as a form of investment and saving for retirement, ideally embodied the libertarian utopia. As we will see in the next section, this positive projection was accompanied by a dystopian vision in which Bush drew the image of a much riskier future, characterized by the imminent demise of the retirement system.

\section{The Bush administration's Social Security reform project}

Intent on advancing Social Security reform after his reelection, Bush prominently addressed the ownership society in his second Inaugural Address on January 20, 2005, emphasizing it as part of his core domestic political vision in a speech characterized by highly idealistic language. In a previous speech, he had already argued that the US recovered from the September 11 attacks “because we're a strong people, we're resilient, because there's an ownership society, a culture of ownership in America" (Bush, 2006b: 311). Speaking while the US military were fighting in Afghanistan and Iraq, Bush dedicated his Inaugural Address to America's ideal of freedom, using the term 'freedom' to bracket foreign and domestic politics. Relying on freedom as a floating signifier allowed Bush to invoke the ideals of the American Revolution and extend them to the arena of world politics. Acknowledging that the US, "[f]rom the day of [its] founding, [had] proclaimed that every man and woman on this Earth has rights and dignity and matchless value", it appeared as America's "mission" to expand "freedom in all the world" (Bush, 2007d: 66). Bush employed the term 'freedom' in the sense of a negative liberty, the absence of tyranny and oppression. The term also blends the freedom of the individual with that of a political community; it denotes "the imperative of self-government, because no one is fit to be a master and no one deserves to be a slave" (Bush, 2007d: 66). Invoking slavery, Bush also implicitly alludes to the positive connotations the term 'freedom' gained in the struggle of African Americans in the context of abolitionism and during the Civil Rights Movement. Due to the abstractness of his terms, 'liberty' and 'freedom' remain unspecific; as he invokes notions of 'self-government' and slavery, however, 'liberty' can be most strongly be interpreted as economic freedom, as the right to one's own body and labor.

Turning from foreign policy to domestic issues, this primarily economic understanding of freedom enables Bush to link these two spheres:

In America's ideal of freedom, citizens find the dignity and security of economic independence instead of laboring on the edge of subsistence. This is the broader definition of liberty that motivated the Homestead Act, the Social Security Act, and the Gl bill of rights. And now we will extend this vision by reforming great institutions to serve the needs of our time. To give every American a stake in the promise and future of our country, we will bring the highest standards to our schools and build an ownership society. We will widen the ownership of homes and businesses, retirement savings, and health insurance, preparing our people for the challenges of life in a free society. By making every citizen an agent of his or her own destiny, we will give our fellow Americans greater freedom from want and fear and make our society more prosperous and just and equal. (Bush, 2007d: 68)

Freedom in Bush's rhetoric possesses a utopian quality: the ideal is both a legacy of the Founding Fathers and a promise of the future, of an ultimately just society in which all citizens are truly equal. Speaking of "dignity" and "security", he endows independence with a moral significance and an affective dimension. To give people in other parts of the world dignity through economic freedom is supposed to foster national security, just as economic 
independence is a source of security and dignity for American citizens. Moreover, he contrasts economic independence with "laboring at the edge of subsistence", thus implying that individuals can only flourish through economic self-determination. Invoking the Homestead Act, the Social Security Act and the GI bill of rights as great achievements of the commitment to liberty - three landmark pieces of legislation that helped to distribute wealth more equally among Americans in the past (Brown et al., 2005: 14) - Bush announces his intent to remake these "great institutions to serve the needs of our time". He thus puts his own proposals in line with these former acts while at the same time advancing legislation changing their fundamental character, justifying his intervention as progressive future-orientation. In Bush's rhetoric, the commitment to ownership appears at the symbolic core of American values, also underlined by his allusion to Roosevelt's 'Four Freedoms' speech at the end of the passage cited above. Bush here compares himself to Roosevelt as both inventor of Social Security and wartime president, reestablishing the link between world politics and domestic policy.

For Bush, freedom, understood as economic liberty, bears a large moral significance: "the public interest depends on private character, on integrity and tolerance toward others and the rule of conscience in our own lives. Self-government relies, in the end, on the governing of the self" (Bush, 2007d: 68). The autonomy of the self depends on disciplining the self; successful membership in the ownership society requires an adherence to conservative moral values, "character" which is "built in families, supported by communities with standards" (Bush, 2007d: 68). The reform of social institutions through their privatization and financialization thus here is also promoted as "a way to develop the self" (Martin, 2002: 9). The autonomous self thus learns to accept and manage ever higher risks at a moment in which the institutional structures meant to soften these risks are being dismantled, foremost among them Social Security.

These values can be traced back to the influential thought of Friedrich von Hayek and Milton Friedman, who from as early on as the 1960s, characterized Social Security as the instrument of an ever-expanding welfare state that encroached on individual liberties. Both criticized Social Security's compulsory nature, as well as the state monopoly on providing Social Security insurance. They also suggested that Social Security did not work like insurance, and had to be understood as a coercive income redistribution scheme (Hayek, 1960: 285305; Friedman, 1962: 182-89). The system of retirement benefits, Friedman argued, was to the advantage of those who entered the system at a later age, at the expense of someone who entered young. In such a case, wealth was redistributed from the young to the old, independently of the participants' wealth (Friedman, 1962: 184). Friedman also questioned that such a system would be self-financing in the long run, making subsidies from the general taxpayers necessary. Both he and Hayek saw redistribution of this kind as immoral. Even more starkly, Nozick (1974: 169) suggests more generally that any kind of "[t]axation of earnings from labor is on par with forced labor", because it requires a person to work more hours than he or she will effectively be paid. According to this argument, taxation is equivalent to "seiz[ing] some of a man's leisure [...] for the purpose of serving the needy" (Nozick, 1974: 170), and therefore deeply illegitimate. Thus for Hayek, Friedman, and Nozick, Social Security is ultimately irreconcilable with their understanding of individual autonomy, and represents a state-mandated system of redistribution that creates a culture of dependency and undermines self-reliance (Avsar, 2008: 126-27). These arguments highlight how the debate around Social Security centers on a conflict between two fundamentally different visions of society: "Social Security", Mark Levinson (2005: 34) points out, "is based on the socialization of concern, the vision of society as a community, which even if not based on truly egalitarian principles, at least modulates the heartlessness of 'rugged individualism'”. 
In his second term in office, Bush could directly point to the alleged success of his previous policies in the housing sector as he proposed to reform Social Security. Thereby, he rallied to gather support for a reform project of a popular institution that the public at large did not perceive to be in urgent need of reform (Asen, 2009: 199). In 2001, he had already appointed a bipartisan Commission to Strengthen Social Security that recommended partial privatization. After his reelection, Bush promoted a plan that would allow workers to divert 4\% of their wages from Social Security into a private retirement account. In its current form, Bush argued, Social Security was "headed toward bankruptcy" (Bush, 2007e: 115). According to his administration's calculations, Social Security in its present state would start to pay out more than it took in by 2018 and exhaust its funds by 2042. Framing the trajectory of Social Security's demise as a matter of mathematical calculation, Bush would insist in speeches to various audiences that the system would be "flat bust" or "flat broke" by 2042, insinuating a particularly drastic form of bankruptcy (Asen, 2009: 217). The positive utopia of the ownership society, then, also relied on an implicit, more dystopian alternative, entailing the rhetorical invocation of an impending failure of the present system.

The Bush administration, in relying on financial projections, employed a rhetoric that implied an ability to contain the inherent unpredictability of the future. At the same time, they promised citizens more control over their own uncertain future (wealth) by proposing that they manage their assets themselves instead of relying on the government. While Bush explained that he would not change the present system for workers over the age of 55, he offered "a better deal for younger workers", "personal accounts" to "build a nest egg for your own future" and the option "to pass along the money that accumulates [...] to your children and - or grandchildren. And best of all, the money in the account is yours, and the Government can never take it away" (Bush, 2007e: 116). Bush thus proposed individual and familial profit and security at the expense of social solidarity.

The administration's calculations were highly contested. The liberal economist Paul Krugman (2005: 6) noted that "[t]he distant future play[ed] a strangely large role in the current discussion", as the Bush administration insisted on the urgency of far-reaching policy changes by relying on projections of a future still 30, 40, or 50 years away, sometimes even invoking estimations beyond a 75-year-window common to budget projections. Krugman also drew attention to the administration's rhetorical practice of insinuating that Social Security was financed by a dedicated tax separate from the general budget, while at the same time treating the Social Security trust fund that covered deficits as an integral part of government expenditures. This inconsistency allowed the reform advocates to depict Social Security at once as part of and separate from other government programs, depending on which version was beneficial for the argument they sought to advance (Krugman, 2005: 2). Randall Wray (2005a: 2) called the idea of Social Security's imminent bankruptcy a "preposterous claim". Mark Levinson (2005), chief economist at UNITE HERE, presented a rivaling projection which argued that, while Social Security would indeed pay out more than it took in from 2018 onwards, these expenses would be funded largely through the fund's investment in US Treasury securities, enabling the system to continue through 2053 without changes. After that there would be a $20 \%$ gap in funds needed to pay all scheduled benefits. The missing funds would amount, however, to "only one-half of the tax cut Bush provided the richest $2 \%$ families" (Levinson, 2005: 32).

Bush's liberal opponents were not the only ones to come to such dissenting conclusions. The Social Security Administration itself at the time evaluated the situation far less dramatically than the President and his team. "Even if a trust fund's assets are exhausted," its 2005 report stated, "tax income will continue to flow into the fund. Present tax rates would be 
sufficient to pay $74 \%$ of scheduled benefits after trust fund exhaustion in 2041 and $68 \%$ of scheduled benefits in 2079" (Board of Trustees, 2005: 8). Even though the system would still continue to pay benefits reduced to three quarters of scheduled benefits after 2042, Bush misrepresented the financial situation as total demise (Asen, 2009: 218). In their long-range projection, Social Security's imbalance would only be $0.6 \%$ of GDP at the end of 75-year window (Board of Trustees, 2005: 10) - a gap which could be remedied by a modest increase in taxes. ${ }^{12}$

Bush's Social Security reform triggered a large public debate on privatization. ${ }^{13}$ Many of Bush's critics were not only wary of the projections for Social Security's future, but also doubtful about the promised advantages of partial privatization. They feared that the reform would lead to an even earlier depletion of Social Security funds as contributions by younger workers were partly taken out of the solidarity system. They also criticized the notion that individuals would make better investment decisions and generate greater returns than the trust fund invested in US treasury bonds. The administration's argument here was based on the assumptions that stocks would always yield greater returns than bonds, thereby projecting the experience of the past as a law for the future (Krugman, 2005: 4-5). More likely, private investments would turn out more risky and be more severely subjected to financial market cycles (Levinson, 2005: 33-34). Such privatization, Wray (2005a: 3) argues, "would produce high management fees for Wall Street and low returns for tomorrow's seniors”. Unsurprisingly, the plan was backed by the largest benefactors of privatization, the finance and insurance industries (Soederberg, 2007: 104).

\section{Consequences of ownership discourse}

Bush's Social Security reform project ultimately failed to come to fruition. Congress did not pass any Social Security legislation before the Congressional elections of 2006, in which Democrats gained majorities in both Senate and House. The window of opportunity for conservatives to reshape the solidarity system had - at least temporarily - closed. Yet despite this setback, the campaign to reform Social Security had far-reaching consequences, as it raised doubt about the program in the public mind. As a result of these political debates, "insurance no longer reigns supreme as a guiding principle of retirement policy" (Asen, 2009: 231). The fact that the fundamental values of Social Security have been called into question impacts on future discussions, potentially paving the way for new schemes of privatization and financialization.

The Bush administration and its conservative allies promoted the ownership society in order to create a hegemonic social discourse that made reshaping the social institutions look desirable and expedient to the public at large. An ownership society would have meant a further limitation of public investments, which in effect redistributed wealth, and thereby produced a shift from communal solidarity to individual risk. The ownership society put trust in the forces of the market as an allegedly more 'natural' way of organizing the social and adapting to the needs of the times. Its proponents aimed to convince the public that a community that put the self-interested and responsible individual at its center was a more attractive and more future-oriented society than the one brought into being during the New Deal era. The ownership society constituted a political vision that attempted to establish the property-owning individual as an identity category, thereby building a political coalition around the notion of property ownership. Highlighting citizens as owners with material interests would generate a psychological shift as people holding assets would automatically become interested in protecting their wealth, all the more so if they shouldered considerable financial 
risk. In such a society, "[c]lass consciousness would be a relic" and workers-turned-owners would shift their party affiliation to those political forces committed to protecting their property rights (Klein, 2008: para. 2).

The libertarian utopian vision of the ownership society evoked the image of a democratic community in which every individual participated on equal terms in capitalist wealth creation. However, as Wray (2005b: 30) explains, "the ownership-society reforms would be likely to do the opposite, increasing inequality and concentrating wealth among the owner classes". The image of the US as an ownership society with widespread wealth rests in large part upon the status of the home as a significant asset, owned by families across the spectrum of all income and wealth percentiles. Yet, as Wray (2005b: 22-25) rightly cautioned before the crash of the housing market, the idea of counting homes as wealth is compromised by the fact that many homeowners carry mortgages and escalating burdens of debt, especially in the lower income percentiles. With respect to other financial assets, such as stocks, the wealth distribution is heavily skewed toward higher income groups. In this way,

to equate holding a mortgage family home with membership in a class of 'citizen investors' [...] borders on delusion, because many 'home owners' merely occupy, manage, and improve homes proximately owned by banks and mortgage companies that are in turn owned by the true owner class-those with lots of wealth, particularly financial wealth, but little debt. (Wray, 2005b: 28)

Far from creating a hopeful, future-oriented society without structural hierarchies, a community that puts faith primarily in free market relationships seems to aggravate inequalities, introducing a new hierarchy between owners and non-owners of property, the latter being excluded as legitimate members of the political sphere.

Ironically, then, the vision of the ownership society, with its promise of individual control and non-hierarchical social relationships, appeared particularly attractive in the face of people's increasing experience of expanding risks and dwindling agency during the past quarter century: less job and wage security, fewer unemployment benefits, more precarious health insurance and rising out-of-pocket health-related costs, housing insecurity and education-related debt. These are largely consequences of deliberate political choices to deregulate the markets and cut public funding, the very measures that would have been exacerbated in Bush's ownership society (Brown et al., 2005: 3-7). Rather than reducing insecurity, this vision sought to educate and encourage individuals to embrace and to capitalize on future risks.

Though it promised the inclusion of all citizens, the ownership society ultimately distinguished between owners and non-owners, the latter being excluded as allegedly 'choosing' to opt out or failing to take on the responsibilities of ownership. Yet, with the lower and middle-income classes more exposed to financial risks, asset building for them is less feasible, whereas the new options generated through financialization enabled people with higher incomes to increase their investments, securing their own future risks. The ownership discourse thus curiously inverted risks and responsibilities; it held people responsible for events outside their immediate control - such as job loss and health problems - while framing deliberate political choices as merely reactive to the demands of a changing world and the realization of a 'natural' ideal. The ownership society thus seeks to transform the realm of the political as such, rendering debates about a social redistribution of resources as both immoral and illegitimate. To borrow from Adam Smith (1976: 715), one may come to the conclusion that the ownership society, with its distinct financial temporalities, defends "the rich against the poor, or [...] those who have some property against those who have none at all". 


\section{Notes}

1. I opt to label this movement 'libertarian' in order to underline how its protagonists tend to consider their advocacy of free markets and a minimal state as a moral question. Classical liberals, though often holding similar political positions, generally do so according to utilitarian considerations, viewing free markets approaches as more efficient than those associated with state regulation. In political discourse, the terms 'libertarianism' and 'classical liberalism' are frequently conflated or used interchangeably.

2. Traditional social security contributions are of course also a form of investment in the sense that they are, as required by law, invested in US savings bonds that are non-marketable.

3. Jeremy Waldron (1988) provides a detailed discussion of philosophical arguments advanced in defense of private property. Prominent libertarian perspectives on property and the role of the state include those established by Hayek (1960), Friedman (1962), and Nozick (1974).

4. It is precisely in cases such as the latter that the so-called 'tragedy of the commons' occurs (see Hardin, 1968). Without regulations enforced by a government, companies will have no incentive to protect resources that belong to all, like air and water, because their private gain will outweigh their losses, which will be imposed on society as a whole. These resources, as Hardin (1968: 1245) points out, "cannot readily be fenced", and therefore exploitation needs to be averted through different means, "by coercive laws or taxing devices that make it cheaper for the polluter to treat his pollutants than to discharge them untreated". Such regulations, however, require government institutions; rational market actors who maximize their profits will not voluntarily agree to shoulder the losses.

5. In December 2003, the African American homeownership rate was at 49.4\% (Hispanics: $47.7 \%$; non-Hispanic whites: $75 \%$ ), which in fact was also its peak; the rate then started to decline again, reaching $42.4 \%$ in the third quarter of 2015 , putting it at roughly the same level as in 1995 . The Hispanic homeownership rate peaked at $50.1 \%$ in 2007 and has now dropped to $46.1 \%$. In comparison, the rate for Non-Hispanic whites peaked in 2005 at $76.2 \%$ and has meanwhile declined to 71.9\%, one percentage point higher than in 1995 (US Census Bureau, 2017).

6. As Béland (2007: 94) has pointed out, Bush's rhetoric also draws on Margaret Thatcher's notion of "popular capitalism", which envisioned an ownership society in Great Britain in the 1980s, and invoked a similar discourse on ownership with its moral and economic inflections.

7. The exact definition of which loans should be considered 'predatory' is contested. For an extensive discussion of the term, see Engel and McCoy (2001: 1259-70).

8. A more detailed discussion of the relationship between Bush's rhetoric and the structural conditions of the housing crisis is beyond the scope of this article. Clearly, we cannot attribute the crisis singularly to Bush's promotion of the ownership society. Congress passed policies expanding the subprime mortgage market during the time of the Bush administration, and often did so with bipartisan blessing. At the same time, initiatives to regulate or prohibit predatory lending could not gain enough legislative support. See, for example, Mian et al. (2008).

9. Bush here clearly relied on what Margaret Radin (1993) has termed the 'conservative ideology', seeking to reduce all forms of property to land ownership, which is thought to substantiate individuality and personal liberty. As she writes, "In [this] ideology, land ownership mythologically becomes ownership, and the ideology then mythologically extends to whatever we normally denominate property" (Radin, 1993: 12).

10. According to a June 2006 report by the Government Accountability Office, jurisdictions had spent $\$ 98.5$ million to aid approximately 13,000 families by December 31, 2005 - i.e., during the first two years of ADDI programs; about half of the beneficiaries were minorities (US GAO, 2006: 4). 
11. For Béland (2007: 99), one effect of the rhetorical emphasis on an individualistic and optimistic homeownership discourse was that it diverted attention away from the administration's lack of engagement with the public housing sector. Brown, Kuttner and Shapiro (2005: 5) similarly note that "[t]he federal government, which once subsidized affordable home ownership as well as rental apartments, is no longer subsidizing either except at minuscule levels or through tax writeoffs that disproportionately favor more affluent home owners".

12. This 2005 evaluation, of course, rests on predictions about the future made at that time, before the recession and the current very low interest rates on US Treasury securities. A 2016 report projects a trust fund exhaustion by 2035 ; to remain fully solvent over a 75 -year period, payroll taxes would have to increase by $2.58 \%$, or scheduled benefits would have to be reduced by $16 \%$ for all current and future beneficiaries (Board of Trustees, 2016: 5).

13. For a more detailed discussion of the social security debate, see Asen (2009: 189-231).

\section{References}

Asen, R. (2009) Invoking the Invisible Hand: Social Security and the Privatization Debates. East Lansing, MI: Michigan State University Press.

Asen, R. (2010) The ownership society, or bourgeois publicity revisited. In: Brouwer, D.C. and Asen, R. (eds.) Public Modalities: Rhetoric, Culture, Media, and the Shape of Public Life. Tuscaloosa, AL: University of Alabama Press, 109-30.

Avsar, R.B. (2008) A critique of 'neoliberal autonomy': The rhetoric of ownership society. Forum for Social Economics, 37(2): 125-34.

Béland, D. (2007) Neo-liberalism and social policy: The politics of ownership. Policy Studies, 28(2): 91107.

Board of Trustees, Federal Old-Age and Survivors Insurance and Disability Insurance Trust Funds (2005) The 2005 Annual Report of the Board of Trustees of the Federal Old-Age and Survivors Insurance and Disability Insurance Trust Funds. Washington, DC: G.P.O.

Board of Trustees, Federal Old-Age and Survivors Insurance and Disability Insurance Trust Funds (2016) The 2016 Annual Report of the Board of Trustees, Federal Old-Age and Survivors Insurance and Federal Disability Insurance Trust Funds. Washington, DC: G.P.O.

Boaz, D. (2004) Defining an Ownership Society. Washington, DC: Cato Institute.

Brown, J.L., Kuttner, R., and Shapiro, T.M. (2005) Building a Real 'Ownership Society'. New York, NY: Century Foundation.

Bush, G.W. (2005a) Remarks to the National Summit on Retirement Savings, 28 February 2002. Public Papers of the Presidents of the United States: George W. Bush (2002, Book I). Washington, DC: G.P.O., 308-11.

Bush, G. W. (2006a) Remarks to small investors in Alexandria, Virginia, 12 February 12 2003. Public Papers of the Presidents of the United States: George W. Bush (2003, Book I). Washington, DC: G.P.O., 156-61.

Bush, G.W. (2006b) Remarks in a discussion on the national economy in Bakersfield, California, 4 March 2004. Public Papers of the Presidents of the United States: George W. Bush (2004, Book I). Washington, DC: G.P.O., 309-18.

Bush, G.W. (2006c) Remarks at a Bush-Cheney reception in Dearborn, Michigan, 24 July 2003. Public Papers of the Presidents of the United States: George W. Bush (2003, Book II). Washington, DC: G.P.O., 926-30.

Bush, G.W. (2007a) Remarks following a discussion with small-business entrepreneurs, 2 July 2004. Public Papers of the Presidents of the United States: George W. Bush (2004, Book II). Washington, DC: G.P.O., 1224-33. 
Bush, G.W. (2007b) Remarks in a discussion in Lima, Ohio, 28 August 2004. Public Papers of the Presidents of the United States: George W. Bush (2004, Book II). Washington, DC: G.P.O., 1775-94. Bush, G.W. (2007c) Remarks accepting the presidential nomination at the Republican National Convention in New York City, 2 September 2004. Public Papers of the Presidents of the United States: George W. Bush (2004, Book II). Washington, DC: G.P.O., 1855-63.

Bush, G.W. (2007d) Inaugural address, 20 January 2005. Public Papers of the Presidents of the United States: George W. Bush (2005, Book I). Washington, DC: G.P.0., 66-69.

Bush, G.W. (2007e) Address before a Joint Session of the Congress on the State of the Union, 2 February 2005. Public Papers of the Presidents of the United States: George W. Bush (2005, Book I). Washington, DC: G.P.O., 113-21.

Canova, T.A. (2008) Legacy of the Clinton bubble. Dissent, 55(3): 41-50.

Clinton, W.J. (1995) Remarks on the national homeownership strategy, 5 June 1995. Public Papers of the Presidents of the United States: William J. Clinton (1995, Book I). Washington, DC: G.P.0. 80508.

Cuevas, 0.0. (2012) Welcome to my cell: Housing and race in the mirror of American democracy. American Quarterly, 64(3): 605-24.

Engel, K.C. and McCoy, P.A. (2001) Tale of three markets: The law and economics of predatory lending. Texas Law Review, 80(6): 1255-1381.

Friedman, M. (1962) Capitalism and Freedom. Chicago, IL: University of Chicago Press.

Hardin, G. (1968) The tragedy of the commons. Science, 13(162): 1243-48.

Hayek, F.A. von. (1960) The Constitution of Liberty. Chicago, IL: University of Chicago Press.

Klein, N. (2008) Disowned by the ownership society. The Nation [Online], 31 January. Available at: <https://www.thenation.com/article/disowned-ownership-society/>. Accessed 24 January 2018.

Krugman, P. (2005) Confusions about social security. The Economists' Voice, 2(1): 1-9.

Levinson, M. (2005) Worse than you thought: Bush's budget and the gutting of social security. Dissent, 52(2): 30-34.

Martin, R. (2002) Financialization of Daily Life. Philadelphia, PA: Temple University Press.

Mian, A., Sufi, A. and Trebbi, F. (2008) The political economy of the subprime mortgage credit expansion. Quarterly Journal of Political Science, 8(4): 373-408.

Nozick, R. (1974) Anarchy, State, and Utopia. New York, NY: Basic Books.

Palmer, T.G. (2004) An ownership society fosters responsibility, liberty, properity. Cato Institute [Online], 13 January. Available at: <https://www.cato.org/publications/commentary/ownership-societyfosters-responsibility-liberty-prosperity>. Accessed 24 January 2018.

Radin, M.J. (1993) Reinterpreting Property. Chicago, IL: University of Chicago Press.

Smith, A. (1976) An Inquiry into the Nature and Causes of the Wealth of Nations. Glasgow Edition of the Works and Correspondence of Adam Smith. 2 Volumes. Oxford: Oxford University Press.

Soederberg, S. (2007) Freedom, ownership, and social (in-)security in the United States. Cultural Critique, 65(1): 92-114.

United States Census Bureau (2017) Quarterly rate of homeownership by race and ethnicity of householder: 1994 to present. Available at:

<http://www.census.gov/housing/hvs/data/histtabs.html>. Accessed 24 January 2018.

United States Government Accountability Office (2006) Hud homeownership programs: Data limitations constrain assessment of the American Dream Downpayment Initiative. Report to Congressional Committees, GAO-06-677(2006) [Online]. Available at: <https://www.gao.gov/assets/260/250683.pdf> Accessed 24 January 2018.

Waldron, J. (1988) The Right to Private Property. Oxford: Clarendon.

Wehner, P.H. (2005) Memo on social security. Wall Street Journal [Online], 5 January. Available at: <https://www.wsj.com/articles/SB110496995612018199>. Accessed 24 January 2018. 
Wray, L.R. (2005a) Manufacturing a crisis: The Neocon attack on social security. Levy Economics Institute Policy Note, 2005/2. Available at: <http://www.levyinstitute.org/pubs/pn05_2.pdf>. Accessed 24 January 2018.

Wray, L.R. (2005b) The ownership society: Social security is only the beginning. Levy Economics Institute Policy Note, No. 82. Available at: <http://www.levyinstitute.org/pubs/ppb_82.pdf>. Accessed 24 January 2018. 